\title{
ФІЗИЧНА РЕАБІЛІТАЦІЯ ПРИ ГРИЖАХ ПОПЕРЕКОВОГО ВІДДІЛУ ХРЕБТА
}

\author{
В. Б. Коваль, Д. В. Коваленко \\ Тернопільський національний медичний університет \\ імені І. Я. Горбачевського МОЗ Украӥни
}

У статті описано поняття «грижа міжхребцевого диска». Виділено причини появи грижі. Основну увагу приділено ефективним методам реабілітації грижі.

\section{PHYSICAL REHABILITATION FOR LUMBAR SPINE HERNIAS}

\author{
V. B. Koval , D. V. Kovalenko \\ Horbachevsky Ternopil National Medical University
}

The concept of intervertebral disc herniation was described in the article. The causes of hernias are highlighted. The main focus was on effective hernia rehabilitation techniques.

Вступ. Грижа міжхребцевого диска - це один із найсерйозніших проявів остеохондрозу, який являє собою дистрофічні зміни в хребті. Найчастіше грижі виникають у віці від 20 до 50 років і старше. Міжхребцева грижа - це зміщення деформованого міжхребцевого диска. При цьому захворюванні людина на тривалий час може втратити працездатність, а часто - стає причиною інвалідності. Першим і найголовнішим симптомом, який свідчить про таку патологію, є сильний біль, який з'являється через розрив міжхребцевого диска. Грижа, яка утворилася, випинається назад або в сторону, стискає нерв, призводить до запалення і набряку. Сильний біль через защемлення нерва відчувають у нозі, в кінцівці з'являється слабкість, знижується чутливість внутрішньої сторони стопи, нижньої частини гомілки або інших частин ноги [1].

Основна частина. Грижа міжхребцевого диска може проявитися при різних обставинах. Найпоширенішими випадками є поява характерного болю після фізичного перенапруження, незручного положення за робочим столом, після підняття важких предметів, посттравматичного генезу. Втім, сильний біль, може виникнути і раптово, коли нічого не провокувало його. Біль, який спричиняє грижа міжхребцевого диска, може посилюватися і ставати ще інтенсивнішим навіть при найменших рухах хворого.
Причин виникнення грижі хребта в поперековому відділі може бути кілька. Найчастіше грижі супроводжують таке захворювання, як остеохондроз, що $€$ наслідком старіння хребта в силу вікових змін організму або неправильного способу життя [2]. Крім того, до деформацій диска призводять травми: при різкому русі тіла вперед, а потім назад (характерно для дтП), неакуратному піднятті важких предметів за рахунок напруження м'язів спини, а не ніг. Важливе значення в розвитку гриж хребта має спосіб життя людини. Повна відсутність фізичних навантажень істотно послаблює м'язовий корсет, уповільнює обмінні процеси в організмі. Тому міжхребцеві грижі характерні для людей «сидячих» професій: офісних працівників або водіїв. Гіподинамія і адинамія призводять до появи надмірної маси тіла. При цьому еластичність дисків знижується, а навантаження на хребет зростає, що і призводить до появи гриж. Однак при цьому надмірні фізичні навантаження також небезпечні для спини. Наявність таких шкідливих звичок, як куріння, регулярне вживання кофеїну, незбалансоване харчування позбавляє хребет необхідних мікроелементів і послаблює його. Не можна також забувати про професійні деформації, що виникають при тривалому перебуванні хребта в одному положенні, що порушує природні обмінні процеси тканин хребця [3].

(ㄱ В. Б. Коваль, Д. В. Коваленко, 2021 
Ефективною методикою реабілітації при грижі хребта $є$ його витягування. Грижу міжхребцевого диска таким способом лікували з давніх часів, але особливо жвавий інтерес до цієї методики виник останнім часом. За допомогою витягування в міжхребцевому просторі створюється перепад тиску, завдяки чому грижа диска нібито всмоктується. Цю процедуру може рекомендувати тільки лікар, і проходити вона повинна під його контролем. При витягуванні хребта важливо знайти правильний напрямок впливу і підібрати відповідне зусилля. В іншому випадку можна ушкодити хребет. Якщо процедуру проводити за правилами, то біль, який спричиняє грижа диска, поступово повинен зменшуватися.

Комплексне лікування обов'язково включає методики мануальної терапії, які успішно застосовують на практиці лікарі, а також лікувальну фізкультуру. Рекомендовані вправи пацієнт може виконувати самостійно, в домашніх умовах. Це відмінна міра профілактики, яка дозволить запобігти виникненню повторних нападів [4].

Крім перерахованих методик і технологій, грижу міжхребцевого диска лікують ще й оперативним способом. Операцію рекомендують в тому випадку, коли, незважаючи на повний комплекс лікувальних процедур, больовий синдром не зменшується протягом 3 тижнів аж до 3 місяців, порушуються функції тазових органів, знижується потенція, після операції необхідний тривалий відновлювальний період та потрібно строго дотримуватися всіх рекомендацій.

Грижа міжхребцевого диска $є$ найпоширенішим тяжким проявом остеохондрозу хребта. При грижі роз-

\section{СПИСОК ЛІТЕРАТУРИ}

1. Антонов І. П. Профілактика неврологічних проявів поперекового остеохондрозу: проміжні підсумки, невирішені питання і деякі методологічні аспекти / І. П. Антонов, Е. В. Барабанова. - М. : ДПК, 2018. - 320 с.

2. Толумбаева Н. С. Грыжа диска позвоночника диагностика и лечение [Электронный ресурс] / Н. С. Толумбаева. - Режим доступа : https://cyberleninka.ru/article/n/ gryzha-diska-pozvonochnika-diagnostika-i-lechenie. вивається больовий синдром, який може супроводжуватися паралічем м'язів нижніх кінцівок, порушенням чутливості, порушенням функції органів малого таза. Більшість пацієнтів із грижами міжхребцевого диска потребує хірургічного лікування.

При відсутності лікування виникає втрата чутливості статевих органів, нетримання сечі або калу. Як правило, це трапляється при грижі поперековокрижового відділу хребта. В особливо небезпечних випадках міжхребцева грижа «вибухає» всередину спинномозкового каналу і може стиснути спинний мозок, викликати параліч [5].

Саме тому варто звернути увагу на перші симптоми захворювання: спочатку завжди починає боліти спина, потім, залежно від локалізації міжхребцевої грижі, приєднуються нестабільність артеріального тиску, головний біль, запаморочення, біль та обмеження рухливості в плечових суглобах, оніміння в пальцях рук, біль і напруження в м'язах шиї та потилиці, міжреберна невралгія, біль в серці, біль і оніміння в правій або лівій нозі (рідше в двох одразу), постійний біль у попереку, втрата чутливості статевих органів, нетримання сечі або калу.

Висновки. Лікування міжхребцевої грижі є складним завданням, яке вимагає високої підготовки лікарів, правильна діагностика має найважливіше значення при виборі схеми лікування з використанням сучасних протизапальних препаратів. При відсутності лікування, з'являються ускладнення і найнебезпечнішим є защемлення грижі, що може спровокувати параліч м'язів верхніх і нижніх кінцівок, тимчасову втрату працездатності та інвалідність.

3. Епифанов В. А. Остеохондроз позвоночника (диагностика, лечение, профилактика) / В. А. Епифанов, А. В. Епифанов. - М. : МЕДпресс-информ, 2008. - 272 с.

4. Лазарєва О. Б. Фізична реабілітація при хірургічному лікуванні вертеброгенних попереково-крижових синдромів : [монографія] / О. Б. Лазарєва. - К., 2017. 328 c.

5. Кремер Ю. Захворювання міжхребцевих дисків / Ю. Кремер ; пер. з англ. - М. : Медпрес-Інформ, 2016. 472 c. 